\title{
PERUBAHAN DAN PREDIKSI PENGGUNAAN LAHAN RUANG TERBUKA HIJAU DI KOTA DEPOK
}

\section{Change and Prediction of Green Open Space Land Use in Depok City}

\author{
Gunarso Primada Aji1)*, Muhammad Ardiansyah²), dan Andi Gunawan3) \\ 1)Program Studi Ilmu Perencanaan Wilayah, Sekolah Pascasarjana IPB University, J1. Lingkar Akademik, Kampus \\ IPB Dramaga, Bogor 16680 \\ 2)Departemen Ilmu Tanah dan Sumberdaya Lahan, Fakultas Pertanian IPB University, Jl. Meranti, Kampus IPB \\ Dramaga, Bogor 16680 \\ 3)Departemen Arsitektur Lanskap, Fakultas Pertanian IPB University, Jl. Meranti, Kampus IPB Dramaga, Bogor \\ 16680
}

\begin{abstract}
Urban development tends to marginalize GOS (Green Open Space) as an urban ecological function. In the 1996-2000 period, Depok City placed the built-up area as the dominant land use and the land use that has the function of GOS was reduced by 87 ha. For planning and controlling land use change, information on changes and prediction of GOS needs to be known. This study aims to identify GOS land use in 2006, 2013 and 2019; to predict GOS in 2031 and to analyze the GOS needs. The analytical methods used include interpretation of GeoEye images, overlapping land use maps, land use prediction with CAMarkov and assessment of GOS needs. The results show that built-up area increased significantly by 3,579 ha in the 2006-2019 period, while GOS decreased by 167 ha. In 2019, GOS in the city of Depok has not been met the minimum requirement of $30 \%$ of the total area as mandated by the Spatial Planning Law no. 26 of 2007 and still requires 3,087 ha of RTH. This shortage will increase in the future because the prediction of GOS in 2031 decreases and this condition makes the need for GOS in Depok City increase to 3,139 ha.
\end{abstract}

Keywords: CA-Markov, GOS (green open space) needs, prediction of GOS

\section{ABSTRAK}

Pembangunan dan pengembangan kota cenderung mengorbankan RTH (Ruang Terbuka Hijau) sebagai fungsi ekologis perkotaan. Periode tahun 1996-2000 Kota Depok menempatkan lahan terbangun sebagai penggunaan lahan dominan dan penggunaan lahan yang mempunyai fungsi RTH berkurang seluas 87 ha. Untuk menyusun perencanan dan pengendalian alih fungsi lahan informasi perubahan dan prediksi RTH perlu diketahui. Penelitian ini bertujuan untuk mengidentifikasi penggunaan lahan RTH 2006, 2013 dan 2019; untuk memprediksi RTH tahun 2031 dan untuk menganalisis kebutuhan RTH berdasarkan luas wilayah. Metode analisis yang digunakan antara lain interpretasi citra GeoEye, tumpang tindih peta penggunaan lahan, prediksi penggunaan lahan dengan CA-Markov dan penilaian kebutuhan RTH. Hasil menunjukkan bahwa lahan terbangun meningkat signifikan seluas 3,579 ha pada periode 2006-2019, sedangkan RTH berkurang 167 ha. Pada 2019, RTH di kota Depok belum mencukupi syarat minimal 30\% dari total luas wilayah seperti diamanatkan Undang-Undang Penataan Ruang no. 26 tahun 2007 dan masih membutuhkan RTH sebesar 3,087 ha. Kekurangan ini bertambah besar di masa depan karena prediksi RTH tahun 2031 menurun dan kondisi ini membuat kebutuhan RTH di Kota Depok meningkat menjadi 3,139 ha.

Kata kunci: CA-Markov, kebutuhan ruang terbuka hijau (RTH), prediksi RTH

\section{PENDAHULUAN}

Pembangunan suatu wilayah biasanya beriringan dengan proses perkembangan wilayah tersebut. Di dalam pembangunan dan perkembangan wilayah perkotaan selalu terdapat proses alih fungsi lahan yang digunakan untuk memenuhi kebutuhan masyarakat kota akan infrastruktur dan fasilitas yang dibutuhkan dalam perkembangan perkotaan. Proses pembangunan dan pengembangan kota biasanya cenderung memarjinalkan nilai ekologis dari suatu lahan untuk ditukar dengan fungsi yang lebih ekonomis. Putri (2010) menyebutkan RTH (Ruang Terbuka Hijau) sebagai fungsi ekologis perkotaan seringkali dikorbankan dalam membangun dan mengembangkan sebuah kota. Selajutnya menurut Suwarli (2015) marjinalisasi RTH menyebabkan secara ekologis sulit bagi sebuah kota besar untuk dapat mewujudkan atau mempertahankan kawasan lindung sebagai area untuk kelestarian hidrologis.

Penurunan kuantitas lahan yang berfungsi ekologis, terutama RTH pada 30 tahun terakhir sangat signifikan. Luasan RTH di kota besar seperti Jakarta, Surabaya, Medan, dan Bandung telah berkurang dari 35\% pada awal tahun 1970-an menjadi kurang dari $10 \%$ pada saat ini. Ruang terbuka hijau sebagian besar telah menjadi infrastruktur perkotaan seperti jaringan jalan, gedunggedung perkantoran, pusat perbelanjaan, dan kawasan permukiman baru (Siahaan, 2010). Pada periode tahun 1996-2000 penggunaan lahan di Kota Depok untuk pemukiman, jasa, perusahaan dan industri masing-masing bertambah 1,324 ha, 38 ha, 97 ha dan 154 ha. Sementara, penggunaan lahan yang mempunyai fungsi RTH seperti tegalan/kebun dan hutan berkurang seluas 87 ha sebagaimana disitir oleh Kumar (2002) dari data resmi 
Dinas Pertanian dan Perkebunan. Studi lain menyebutkan bahwa luas RTH Kota Depok belum memenuhi proporsi RTH seperti diamanatkan dalam UU RI No. 26 Tahun 2007 tentang Penataan Ruang (Setyani et al., 2017; Ramadhan dan Osly, 2019).

Salah satu kriteria perumusan rencana pola ruang wilayah kota adalah menyediakan RTH minimal 30\% dari luas wilayah kota. Hal tersebut sesuai dengan amanat Undang-Undang Nomor 26 tahun 2007 tentang Penataan Ruang yang mengatur bahwa proporsi RTH pada wilayah kota paling sedikit $30 \%$ dari wilayah luas kota, yang terdiri atas $20 \%$ RTH publik dan 10\% RTH privat. Proporsi $30 \%$ merupakan ukuran minimal untuk menjamin keseimbangan ekosistem kota, baik keseimbangan sistem hidrologi dan sistem mikroklimat, maupun sistem ekologis lain, yang selanjutnya akan meningkatkan ketersediaan udara bersih yang diperlukan masyarakat, serta sekaligus dapat meningkatkan nilai estetika kota.

Sebagai daerah penyangga Jakarta, Kota Depok mendapatkan tekanan migrasi penduduk yang cukup tinggi sebagai akibat meningkatnya kawasan permukiman, pendidikan, perdagangan dan jasa. Hal tersebut akan menempatkan luas RTH semakin sempit dan tidak mencukupi karena alih fungsi lahan. Oleh karena itu monitoring dan prediksi RTH perlu dikaji sebagai dasar untuk menyusun rekomendasi dalam perencanaan dan pengendalian alih fungsi lahan dengan mempertimbangkan RTH.

Penelitian ini bertujuan untuk (1) mengidentifikasi penggunaan lahan tahun 2006, 2013 dan 2019 serta menganalisis perubahannya di Kota Depok, (2) memprediksi penggunaan lahan kota Depok tahun 2031 dan (3) menganalisis kecukupan RTH berdasarkan luas wilayah.

\section{BAHAN DAN METODE}

Penelitian ini dilakukan di Kota Depok, Provinsi Jawa Barat. Data dasar yang digunakan meliputi citra GeoEye perekaman Juni 2006; Agustus 2013 dan Mei 2019, peta batas administrasi dari Bappeda Kota Depok dan data jumlah penduduk BPS Kota Depok (BPS, 2020). Alat yang digunakan adalah komputer dengan software ArcGIS 10.3.1 dan IDRISI Selva serta smartphone yang dilengkapi dengan built-in GPS untuk cek lapang penggunaan lahan RTH.

\section{Identifikasi Penggunaan Lahan dan Analisis Perubahannya}

Penggunaan lahan Kota Depok didapatkan dari hasil interpretasi visual citra GeoEye tahun 2006, 2013 dan 2019 menggunakan software ArcGIS 10.3.1. Interpretasi visual citra merupakan salah satu teknik penginderaan jauh yang telah lama digunakan. Interpretasi visual disebut sebagai metode manual dikarenakan penafsiran citra dilakukan oleh manusia yang merupakan hasil penyimpulan visual citra dengan mengelompokkan piksel citra berdasarkan cirinya yaitu warna, bentuk, ukuran dan tekstur (Lillesand et al., 2015). Hasil interpretasi citra berupa jenis penggunaan lahan yang berpedoman pada SNI 2010:7645 (BSN, 2010) tentang Klasifikasi Penutup Lahan yang disesuaikan dengan kebutuhan penelitian. Penggunaan lahan dibatasi pada kelas RTH (publik dan privat), sawah, kebun campuran, lahan terbangun, semak belukar, lahan terbuka dan tubuh air. Penggunaan lahan hasil interpretasi kemudian divalidasi untuk melihat akurasi dan kebenaran di lapangan menggunakan metode purposive sampling. Analisis perubahan penggunaan lahan diperoleh dengan metode tumpang tindih peta penggunaan lahan tahun 2006, 2013 dan 2019.

\section{Analisis Prediksi Penggunaan Lahan}

Analisis prediksi penggunaan lahan digunakan untuk menduga penggunaan lahan tahun 2031 dengan dasar pertimbangan pada tahun 2032 merupakan berakhirnya Rencana Tata Ruang Wilayah Kota Depok. Analisis ini dilakukan dengan pendekatan metode Markov Chain dan Cellular Automata (CA) menggunakan software IDRISI Selva. Penggunaan metode CA-Markov dalam perubahan penggunaan lahan memiliki banyak keuntungan antara lain kemampuan simulasi yang dinamis, keunggulan akan kelangkaan data dan kalibrasi langsung di lapangan, serta kemampuan untuk mensimulasikan beberapa pola dan penggunaan lahan yang kompleks (Hyandye dan Martz, 2017). Banyak penelitian telah menerapkan model CAMarkov untuk memantau dan menilai perubahan penggunaan lahan dan prediksinya (Munibah, 2008; Mosammam et al., 2016; Nguyen et al., 2017; Wahyudi et al., 2019).

Prediksi penggunaan lahan pada 2031 bersifat business as usual dengan asumsi tren perubahan penggunaan lahan kedepan sama dengan tren historis, sehingga matrik probabilitas dan area transisi (transition suitability) yang digunakan adalah hasil proses metode Markov Chain dengan input penggunaan lahan tahun 2006 dan 2013. Pertama, matriks probabilitas dan transisi dihitung menggunakan modul Markov Chain dengan input peta penggunaan 2006 dan 2013. Berdasarkan peta kesesuaian modul pengambilan keputusan multiobjektif (multicriteria evaluation, MCE) yang tersedia pada IDRISI digunakan untuk menentukan kesesuaian (Eastman, 2012). Filter matriks yang digunakan adalah 5 x 5 yang berarti bahwa perubahan penggunaan lahan pada piksel pusat dipengaruhi oleh nilai 24 piksel tetangganya. Terakhir, prediksi penggunaan lahan tahun 2031 berdasarkan data tahun 2006 dan 2019 dilakukan dengan menggunakan modul CA-Markov yang terintegrasi dalam IDRISI.

Validasi model yang didasarkan pada indeks Kappa digunakan untuk mengukur kesesuaian penggunaan lahan hasil prediksi tahun 2019 dengan penggunaan lahan aktual tahun 2019 menggunakan modul CROSSTAB di IDRISI. Bila indeks Kappa dapat diterima, maka penggunaan lahan 2031 dapat diprediksi.

\section{Kebutuhan RTH berdasarkan Luas Wilayah}

Undang-Undang Nomor 26 tahun 2007 tentang Penataan Ruang mensyaratkan luas RTH 30\% dari total luas wilayah dengan proporsi $20 \%$ RTH publik dan $10 \% \mathrm{RTH}$ privat. Pada penelitian ini, analisis kecukupan RTH dilakukan perhitungan pada masing-masing kecamatan dan luasan RTH tidak dipisahkan antara RTH publik dan privat. 


\section{HASIL DAN PEMBAHASAN}

\section{Identifikasi Penggunaan Lahan dan Analisis Perubahannya}

Penggunaan lahan di Kota Depok tahun 2006, 2013 dan 2019 berdasarkan hasil interpretasi citra terdapat 7 kelas yaitu RTH, kebun campuran, lahan terbangun, lahan terbuka, sawah, semak belukar dan tubuh air, dengan akurasi indeks Kappa lebih besar dari 0.88. Penggunaan lahan terluas tahun 2019 adalah lahan terbangun dengan luas 13,228 ha $(66.04 \%)$. Penggunaan lahan terbangun meliputi pemukiman, sarana komersial (industri, perdagangan dan jasa), sarana pendidikan, sarana perkantoran dan pelayanan masyarakat. Lahan terbangun terluas berada di Kecamatan Tapos seluas 1,839 ha dan Cimanggis dengan luas 1,743 ha, hal tersebut bisa dimengerti karena kecamatan tersebut merupakan konsentrasi kawasan komersial dan pemukiman. Kondisi tersebut diperkuat dengan data jumlah penduduk (BPS 2020), dimana Kecamatan Cimanggis merupakan kecamatan dengan jumlah penduduk paling tinggi sebesar 334,989 jiwa. Ruang terbuka hijau menjadi penggunaan lahan terluas kedua dengan luas 2,922 (14.59\%). Ruang terbuka hijau meliputi hijauan pekarangan rumah, hutan kota dan taman kota. Luas penggunaan lahan per kecamatan di Kota Depok tahun 2019 dapat dilihat pada Tabel 1, sedangkan luas penggunaan lahan dan peta penggunaan lahan Kota Depok tahun 2006, 2013 dan 2019 disajikan pada Tabel 2 dan Gambar 1.

Berdasarkan Tabel 2 dan Gambar 1 perubahan penggunaan lahan periode tahun 2006-2019 cukup signifikan terjadi pada lahan terbangun, kebun campuran dan sawah. Lahan terbangun mengalami penambahan luas 3,579 ha, sedangkan kebun campuran mengalami penurunan luasan 1,706 ha, sawah berkurang 1,375 ha, lahan terbuka menurun 327 ha, dan RTH lebih rendah 167 ha dibandingkan tahun 2006. Laju penurunan RTH pada periode ini lebih rendah dari hasil penelitian Setyani et al. (2017) dengan laju penurunan RTH sebesar 126 ha per tahun. Hal ini disebabkan karena pada penelitian ini interpretasi menggunakan citra resolusi tinggi GeoEye (1.65m x $1.65 \mathrm{~m})$. Penambahan lahan terbangun yang cukup pesat ini menunjukkan fenomena urban sprawl dan proses urbanisasi yang cukup tinggi. Hal ini terjadi dikarenakan Kota Depok berbatasan langsung dengan Provinsi DKI Jakarta serta proses perencanaan dan pengendalian tata ruang wilayah tidak berjalan dengan baik (Zain et al., 2013). Selain itu, faktor lain yang dapat mendorong terjadinya perubahan penggunaan lahan adalah perluasan batas kota, peremajaan pusat kota, perluasan jaringan infrastruktur khususnya jaringan transportasi serta tumbuh dan hilangnya pemusatan aktivitas tertentu (Putra dan Satiawan, 2018).

Tabel 1. Luas penggunaan lahan tahun per kecamatan di Kota Depok tahun 2019

\begin{tabular}{|c|c|c|c|c|c|c|c|}
\hline \multirow{2}{*}{ Kecamatan } & \multicolumn{7}{|c|}{ Penggunaan lahan tahun 2019} \\
\hline & PL 1 & PL 2 & PL 3 & PL 4 & PL 5 & PL 6 & PL 7 \\
\hline Beji & 218 & 110 & 1,119 & 10 & 8 & - & 1 \\
\hline Bojongsari & 260 & 262 & 1,073 & 181 & 137 & - & 13 \\
\hline Cilodong & 109 & 178 & 1,168 & 113 & 46 & - & 11 \\
\hline Cimanggis & 119 & 134 & 1,743 & 113 & 22 & - & 28 \\
\hline Cinere & 77 & 102 & 841 & 22 & 7 & - & - \\
\hline Cipayung & 149 & 161 & 723 & 26 & 25 & - & 7 \\
\hline Limo & 167 & 88 & 825 & 67 & 38 & - & 1 \\
\hline Sawangan & 454 & 432 & 1,348 & 138 & 249 & 1 & 25 \\
\hline Sukmajaya & 233 & 107 & 1,273 & 99 & 6 & - & 11 \\
\hline Tapos & 921 & 222 & 1,839 & 246 & 121 & - & 15 \\
\hline
\end{tabular}

Keterangan: $\quad$ PL 1 = RTH, PL 2 = Kebun Campuran, PL 3 = Lahan Terbangun,

PL $4=$ Lahan Terbuka, PL $5=$ Sawah, PL $6=$ Semak Belukar,

PL 7 = Tubuh Air

Tabel 2. Luas penggunaan lahan Kota Depok tahun 2006, 2013 dan 2019

\begin{tabular}{|c|c|c|c|c|c|c|c|}
\hline \multirow{2}{*}{ No } & \multirow{2}{*}{$\begin{array}{c}\text { Penggunaan } \\
\text { lahan }\end{array}$} & \multicolumn{2}{|c|}{ Luas tahun 2006} & \multicolumn{2}{|c|}{ Luas tahun 2013} & \multicolumn{2}{|c|}{ Luas tahun 2019} \\
\hline & & $\mathrm{Ha}$ & $\%$ & $\mathrm{Ha}$ & $\%$ & $\mathrm{Ha}$ & $\%$ \\
\hline 1 & RTH & 3,089 & 15.42 & 3,033 & 15.14 & 2,922 & 14.59 \\
\hline 2 & Kebun campuran & 3,682 & 18.38 & 2,201 & 10.99 & 1,976 & 9.87 \\
\hline 4 & Lahan terbuka & 1,381 & 6.90 & 1,456 & 7.27 & 1,054 & 5.26 \\
\hline 5 & Sawah & 2,095 & 10.46 & 1,197 & 5.98 & 720 & 3.59 \\
\hline 6 & Semak belukar & 10 & 0.05 & 2 & 0.01 & 1 & 0.00 \\
\hline & Jumlah & 20.029 & 100,00 & 20.029 & 100,00 & 20.029 & 100,00 \\
\hline
\end{tabular}




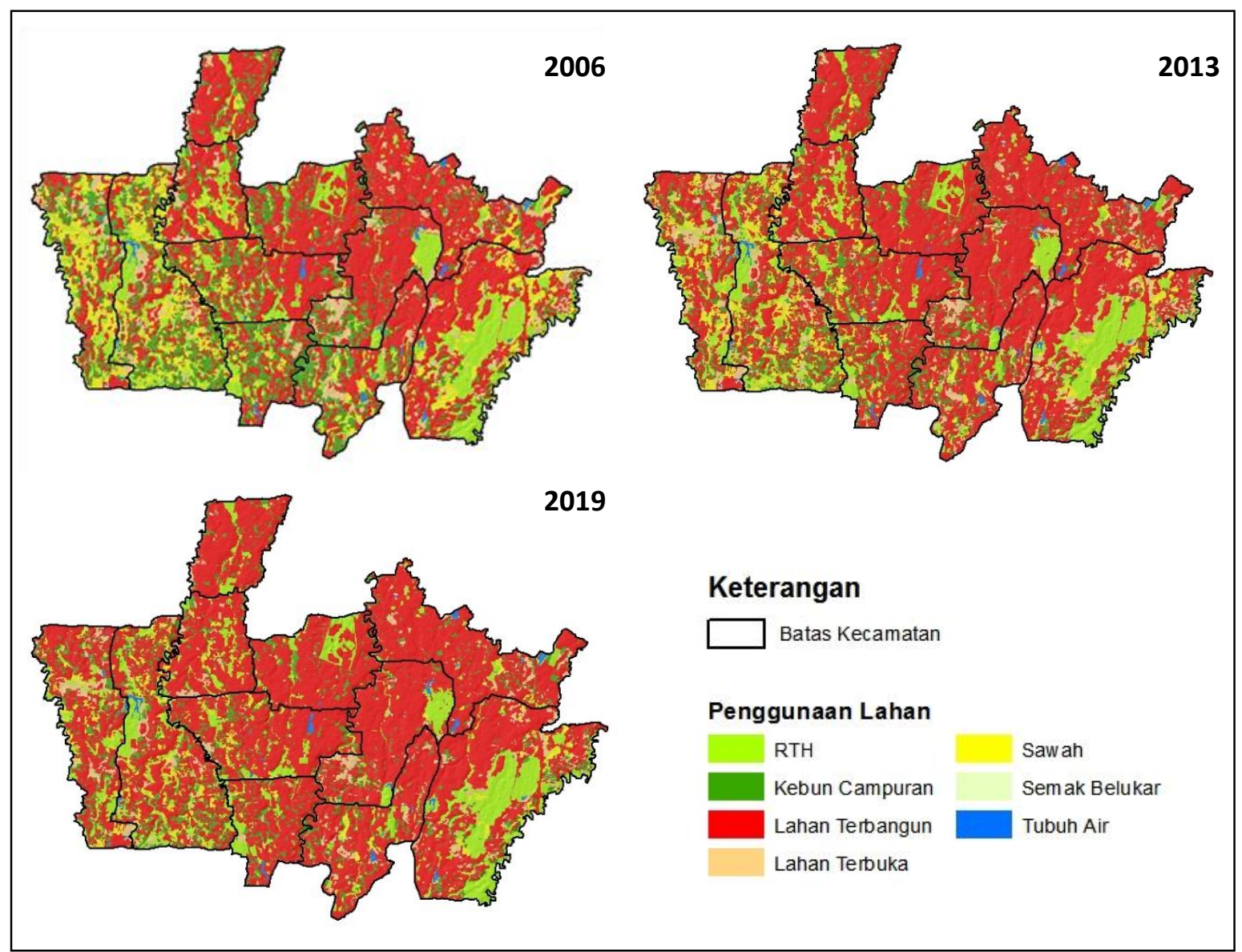

Gambar 1. Peta penggunaan lahan Kota Depok tahun 2006, 2013 dan 2019

\section{Prediksi Penggunaan Lahan}

Tujuan prediksi penggunaan lahan adalah untuk mengestimasi penggunaan lahan pada tahun 2031 sehingga luas dan sebaran RTH dapat diketahui. Model prediksi yang dibangun cukup baik nilai kappa sebesar 0.78 . Menurut Rwanga dan Ndambuk (2017) nilai akurasi Kappa 0.610.80 adalah kecocokan baik sehingga model ini layak digunakan untuk memprediksi penggunaan lahan tahun 2031. Hasil prediksi penggunaan lahan disajikan pada Tabel 3. Penggunaan lahan yang mengalami kenaikan adalah lahan terbangun seluas 2,054 ha (10.26\%), sedangkan penggunaan lahan kebun campuran mengalami penurunan luasan yang cukup tinggi sebesar 1,311 ha $(6.55 \%)$, sawah berkurang seluas 421 ha (2.10\%), dan lahan terbuka sekitar 273 ha $(1.36 \%)$. Sementara luasan RTH hanya mengalami penurunan sebesar 50 ha. Pola perubahan luasan lahan pada penggunaan lahan kedepan (2019-2031) sama dengan pola perubahan luasan penggunaan lahan periode tahun 20062013, dimana luasan lahan terbangun meningkat secara cukup signifikan, sedangkan kebun campuran, lahan terbuka, sawah dan RTH menurun. Untuk RTH hanya berkurang 56 ha pada periode 2006-2913 dan tren historis ini digunakan dalam model prediksi penggunaan lahan. Hal ini membuat prediksi RTH pada 2031 hanya menurun 50 ha dibandingkan 2019, akan tetapi model konsisten memprediksi bahwa RTH Kota Depok akan menurun di masa depan jika tidak ada intervensi perencanan tata ruang dan pengendalian alih fungsi lahan.

\section{Kebutuhan RTH berdasarkan Luas Wilayah}

RTH di perkotaan mempunyai peran menjaga keserasian dan keseimbangan ekosistem lingkungan perkotaan, mewujudkan keseimbangan antara lingkungan alam dengan lingkungan buatan di perkotaan dan meningkatkan kualitas lingkungan perkotaan yang sehat, indah, bersih dan nyaman. Lebih lanjut, menurut Jogo dan Ismaun (2011) RTH berfungsi sebagai pengamanan keberadaan kawasan lindung perkotaan, pengendali pencemaran dan kerusakan tanah, air dan udara, tempat perlindungan plasma nutfah dan keanekaragaman hayati, pengendali tata air dan sarana estetika kota.

Luas RTH eksisting Kota Depok tahun 2019 seluas 2,922 ha. Berdasarkan perhitungan yang disajikan pada Tabel 4, luasan tersebut belum memenuhi persyaratan minimum yang ditentukan oleh undang-undang seluas 6,009 ha sehingga masih terdapat kekurangan 3,087 ha. Kekurangan ini akan bertambah besar di masa depan karena prediksi RTH tahun 2031 berdasarkan tren historis menurun dan kondisi ini membuat kebutuhan RTH di Kota Depok semakin tinggi menjadi 3,139 ha. Strategi peningkatan untuk memenuhi kebutuhan 30\% RTH di Kota Depok dilakukan melalui cara penambahan pohon penyerap polusi di sepanjang koridor ruang hijau seperti jalan arteri, jalan primer, pedestrian sempadan sungai dan sempadan rel kereta (Hayati et al., 2013); penambahan hutan kota dan taman kota; pembelian lahan dari masyarakat untuk digunakan menjadi RTH publik; dan penghijauan berupa taman atap dan taman vertikal pada bangunan/kantor swasta di pusat perdagangan dan jasa. 
Tabel 3. Luas prediksi penggunaan lahan Kota Depok tahun 2031

\begin{tabular}{clrrrrrr}
\hline \multirow{2}{*}{ No } & \multirow{2}{*}{ Penggunaan lahan } & \multicolumn{2}{c}{ Luas tahun 2019 } & \multicolumn{2}{c}{ Luas tahun 2031} & \multicolumn{2}{c}{ Perubahan } \\
\cline { 3 - 8 } & & \multicolumn{1}{c}{ Ha } & \multicolumn{1}{c}{ Ha } & \multicolumn{1}{c}{$\%$} & Ha & \multicolumn{1}{c}{$\%$} \\
\hline 1 & RTH & 2,922 & 14.59 & 2,872 & 14.34 & -50 & -0.25 \\
2 & Kebun campuran & 1,976 & 9.87 & 665 & 3.32 & $-1,311$ & -6.55 \\
3 & Lahan terbangun & 13,228 & 66.04 & 15,282 & 76.30 & 2,054 & 10.26 \\
4 & Lahan terbuka & 1,054 & 5.26 & 781 & 3.90 & -273 & -1.36 \\
5 & Sawah & 720 & 3.59 & 299 & 1.49 & -421 & -2.10 \\
6 & Semak belukar & 1 & 0.00 & - & - & -1 & 0.00 \\
7 & Tubuh air & 128 & 0.64 & 130 & 0.65 & 2 & 0.01 \\
\hline & Jumlah & $\mathbf{2 0 , 0 2 9}$ & $\mathbf{1 0 0 . 0 0}$ & $\mathbf{2 0 , 0 2 9}$ & $\mathbf{1 0 0 . 0 0}$ & & \\
\hline
\end{tabular}

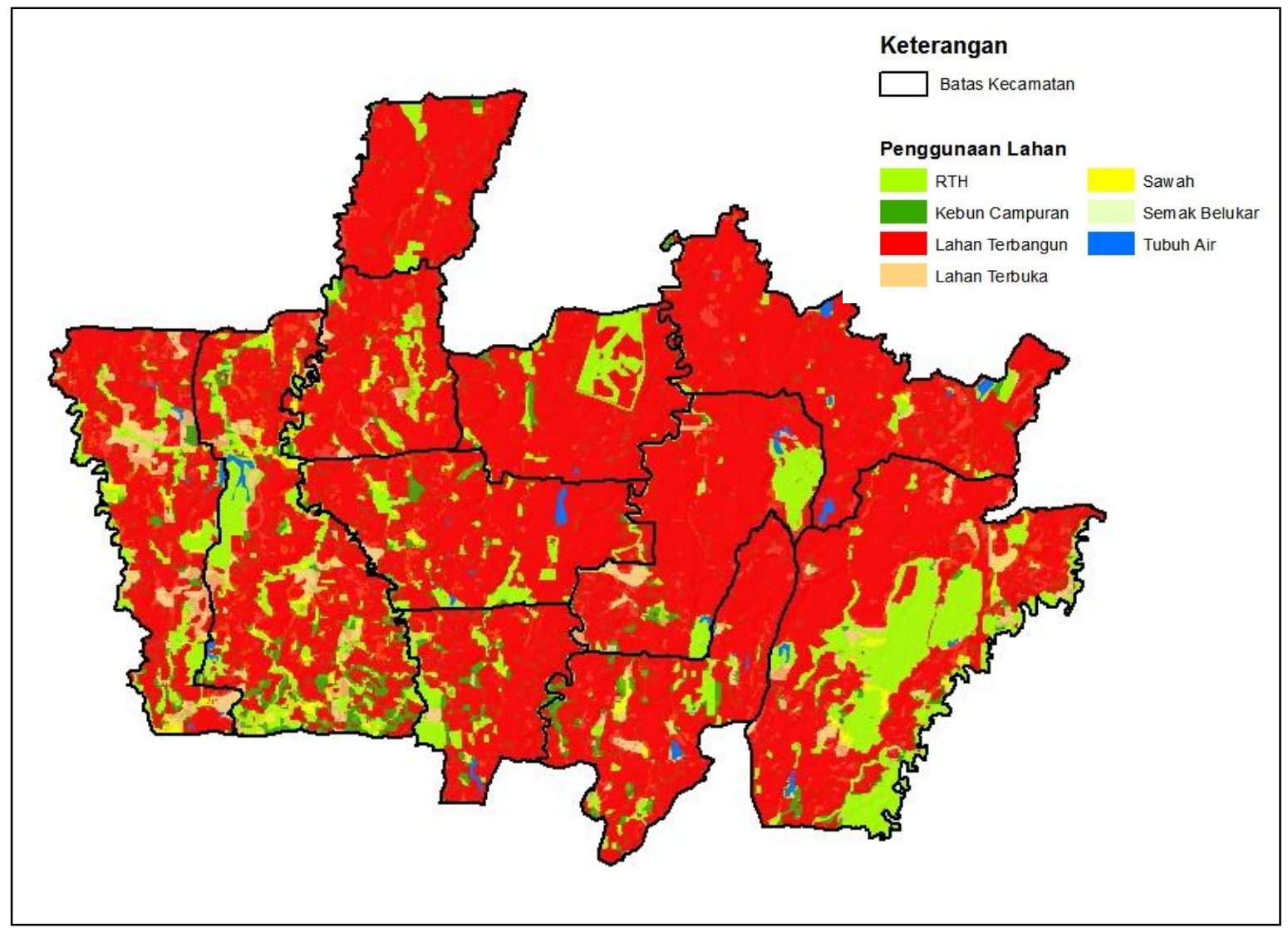

Gambar 2. Peta prediksi penggunaan lahan Kota Depok tahun 2031

Tabel 4. Kondisi eksisting, kebutuhan dan selisih luasan RTH Kota Depok tahun 2019 dan 2031

\begin{tabular}{lrrrrrrr}
\hline \multirow{2}{*}{ Kecamatan } & \multirow{2}{*}{ Luas wilayah } & \multicolumn{3}{c}{ Luasan RTH tahun 2019 } & \multicolumn{3}{c}{ Luasan RTH prediksi tahun 2031 } \\
\cline { 3 - 7 } & & Eksisting & Kebutuhan & Kekurangan & Eksisting & Kebutuhan & Kekurangan \\
\hline Sawangan & 2,619 & 454 & 786 & 332 & 470 & 786 & 316 \\
Bojongsari & 1,930 & 260 & 579 & 319 & 266 & 579 & 313 \\
Pancoran Mas & 1,803 & 213 & 541 & 328 & 203 & 541 & 338 \\
Cipayung & 1,145 & 149 & 344 & 194 & 150 & 344 & 194 \\
Sukmajaya & 1,735 & 233 & 521 & 288 & 225 & 521 & 296 \\
Cilodong & 1,619 & 109 & 486 & 376 & 105 & 486 & 381 \\
Cimanggis & 2,158 & 119 & 647 & 528 & 94 & 647 & 553 \\
Tapos & 3,326 & 921 & 998 & 77 & 911 & 998 & 87 \\
Beji & 1,456 & 218 & 437 & 219 & 216 & 437 & 221 \\
Limo & 1,184 & 167 & 355 & 188 & 173 & 355 & 182 \\
Cinere & 1,054 & 77 & 316 & 239 & 57 & 316 & 259 \\
Jumlahyyyyyyyyy & 20,029 & 2,922 & 6,009 & 3,087 & 2,870 & 6,009 & 3,139 \\
\hline
\end{tabular}

\section{SIMPULAN}

Pada periode 2006-2019, lahan terbangun meningkat signifikan seluas 3,579 ha, sedangkan penggunaan lahan RTH berkurang 167 ha. Penggunaan lahan lain yang mengalami penurunan luas adalah kebun campuran, sawah dan lahan terbuka dengan total mencapai 3,408 ha.
Prediksi penggunaan lahan tahun 2031 berdasarkan tren historis 2006-2013 memperlihatkan lahan terbangun diperkirakan konsisten mengalami peningkatan paling besar mencapai 2,054 ha, sedangkan penggunaan lahan RTH diperkirakan menurun seluas 50 ha, meskipun demikian model konsisten memprediksi bahwa RTH Kota Depok akan menurun di masa depan.

Kebutuhan RTH Kota Depok berdasarkan luas wilayah adalah 6,009 ha, dimana RTH eksisting tahun 2019 
hanya mencapai 2,922 ha sehingga terdapat kekurangan seluas 3,087 ha. Kekurangan ini akan bertambah besar di masa depan karena prediksi RTH tahun 2031 berdasarkan tren historis menurun dan kondisi ini membuat kebutuhan RTH di Kota Depok meningkat menjadi 3,139 ha.

\section{UCAPAN TERIMA KASIH}

Ucapan terima kasih disampaikan kepada Pusbindiklatren Bappenas sebagai sponsorship penelitian ini dan pihak-pihak yang membantu dalam menyelesaikan penelitian ini.

\section{DAFTAR PUSTAKA}

[BPS] Badan Pusat Statistik Kota Depok. 2020. Kota Depok dalam Angka 2020. Badan Pusat Statistik Kota Depok, Depok.

[BSN] Badan Standardisasi Nasional. 2010. Klasifikasi Penutup Lahan. Badan Standardisasi Nasional. Jakarta.

Eastman, J.R. 2012. IDRISI Selva Manual and Tutorial Manual Version 17. Clark University, Worcester USA.

Hayati, J., S.R.P. Sitorus dan S. Nurisjah. 2013. Pengembangan ruang terbuka hijau dengan pendekatan kota hijau di Kota Kandangan. Jurnal Tata Loka, 15(4): 306-316.

Hyandye, C. and L.W. Martz. 2017. A markovian and cellular automata land-use change predictive model of the Usangu Catchment. International Journal of Remote Sensing, 38(1): 64-81.

Jogo, N. dan I. Ismaun. 2011. RTH 30\%! Resolusi (Kota) Hijau. Gramedia Pustaka Utama, Jakarta.

Kumar, K. 2002. Penataan Ruang sebagai Dasar Pengelolaan Lingkungan (Pengkajian Ruang Terbuka Hijau Kota Depok) [Thesis]. UI, Depok.

Lillesand, T.M., R.W. Kiefer and J.W. Chipman. 2015. Remote Sensing and Image Interpretation. 7th Edition. John Wiley \& Sons, Inc. New Jersey.

Mosammam, H.M., J.T. Nia, H. Khani, A. Teymouri and M. Kazemi. 2016. Monitoring land use change and measuring urban sprawl based on its spatial forms: The case of Qom City. The Egyptian Journal or Remote Sensing and Space Science, 20: 103-116.

Munibah, K. 2008. Model spasial perubahan penggunaan lahan dan arahan penggunaan lahan berwawasan lingkungan (Studi kasus DAS Cidanau, Provinsi Banten) [Disertasi]. IPB, Bogor.

Nguyen, T.A., P.M.T. Le, T.M. Pham, H.T.T. Hoang, M.Q. Nguyen, H.Q. Ta, H.T.M. Phung, H.T.T. Le and L. Hens. 2017. Toward a sustainable city of tomorrow: a hybrid markov-cellular automata modeling for urban landscape evolution in the Hanoi City (Vietnam) during 1990-2030. Environment, Development and Sustainability, 21(1): 429-446.

Putra, A.A.A.S.P. dan P.R. Satiawan. 2018. Perumusan faktor-faktor perubahan penggunaan lahan akibat pembangunan Jalan Tol Waru - Juanda di Kelurahan Tambakoso Kabupaten Sidoarjo. Jurnak Teknik ITS, 7(2): C173-C179.

Putri, P. 2010. Analisis spasial dan temporal perubahan luas ruang terbuka hijau di Kota Depok. Jurnal Lanskap Indonesia, 2(2): 115-121.

Ramadhan, F. dan J. Osly. 2019. Analisis ketersediaan ruang terbuka hijau dan kecukupannya di Kota Depok. Jurnal Infrastruktur, 5(1): 7-11.

Rwanga, S.S. and J.M. Ndambuki. 2017. Accuracy assessment of land use/land cover classification using remote sensing and GIS. International Journal of Geosciences, 8: 611-622.

Setyani, W., S.R.P. Sitorus dan D.P. Panuju. 2017. Analisis ruang terbuka hijau dan kecukupannya di Kota Depok. Buletin Tanah dan Lahan. Januari 2017: 121-127.

Siahaan, J. 2010. Ruang publik: Antara harapan dan kenyataan. Buletin Tata Ruang, IV: 11-16.

Suwarli, H. 2015. APBD hijau dan politik penganggaran tata ruang. Prosiding Pertemuan Ilmiah Tahunan (PIT) Nasional ke-2, Ikatan Widyaiswara Indonesia (IWI) Provinsi Banten, Pandeglang, 3 4 Desember 2015. IWI, Pandeglang.

Wahyudi, ME, K. Munibah dan Widiatmaka. 2019. Perubahan penggunaan lahan dan kebutuhan lahan permukiman di Kota Bontang, Kalimantan Timur. Tataloka, 21(2): 267-284.

Zain, A.F.M., G. Syahban dan M. Ermyanyla. 2013. Analisis perubahan peruntukan lahan pertanian perkotaan (urban agriculture) menjadi non pertanian di Kota Depok. Prosiding Lokakarya Nasional dan Seminar Forum Komunikasi Perguruan Tinggi Pertanian Indonesia; 2017 Oktober 2; Bogor, Indonesia. IPB, Bogor. 